\title{
CCK Antagonists Reveal That CCK-8 and JMV-180 Interact With Different Sites on the Rat Pancreatic Acinar Cell $\mathrm{CCK}_{\mathrm{A}}$ Receptor
}

\author{
DAVID I. YULE ${ }^{1}$ AND JOHN A. WILLIAMS \\ Departments of Physiology and Internal Medicine, University of Michigan, Ann Arbor, MI 48109
}

Received 30 November 1993

\begin{abstract}
YULE, D. I. AND J. A. WLLIAMS. CCK antagonists reveal that CCK-8 and JMV-180 interact with different sites on the rat pancreatic acinar cell $C C K_{A}$ receptor. PEPTIDES 15(6) 1045-1051, 1994.-The ability of $C C K_{\mathrm{A}}$ antagonists to inhibit full and partial CCK agonists of the rat pancreatic acinar cell $\mathrm{CCK}_{\mathrm{A}}$ receptor has been studied. When isolated rat pancreatic acini were superfused with CCK-8 (10 $\mathrm{p} M-1 \mathrm{n} M)$ or CCK-4 $(1 \mu M)$, an increase in $\left[\mathrm{Ca}^{2+}\right]_{\mathrm{i}}$ signal was initiated. Concurrent superfusion of either $\mathrm{L}-364,718(0.1 \mu M)$ or lorglumide $(10 \mu M)$, chemically distinct, specific, potent antagonists of the $\mathrm{CCK}_{\mathrm{A}}$ receptor, resulted in a rapid inhibition of the $\left[\mathrm{Ca}^{2+}\right]_{i}$ signal initiated by all concentrations of CCK-8. In contrast, $\mathrm{Ca}^{2+}$ oscillations, initiated by JMV-180 (25 $\left.\mathrm{n} M-1 \mu M\right)$, a partial agonist analogue of CCK-8, were essentially unaffected by concurrent superfusion of either L-364,718 or lorglumide. When JMV-179, an analogue of JMV-180 that exhibits characteristics of a pure antagonist, was superfused concurrently with either CCK-8 or JMV-180, $\mathrm{Ca}^{2+}$ oscillations were inhibited, even in the presence of $0.1 \mu M \mathrm{~L}-364,718$. In a similar fashion, amylase secretion stimulated by CCK8 was markedly attenuated by L-364,718, lorglumide, and JMV-179, whereas secretion stimulated by JMV-180 was only inhibited by JMV-179. A model is proposed to reconcile this data, based on the assumption that JMV-180 and CCK-8 interact with discrete sites on the $\mathrm{CCK}_{\mathrm{A}}$ receptor, which are differentially affected by the binding of antagonists. This model may also explain how a single receptor may transduce multiple signals in response to different agonists.
\end{abstract}

Cholecystokinin JMV-180 Antagonists $\left[\mathrm{Ca}^{2+}\right]_{\mathrm{i}}$ oscillations Pancreatic acinar cells Amylase secretion

CHOLECYSTOKININ (CCK) binding to specific receptors on the plasma membrane of pancreatic acinar cells results in a cascade of intracellular events that ultimately lead to a variety of biological responses, including digestive enzyme secretion $(29,30)$. Investigation of CCK binding to its receptor has revealed that the receptor exists in multiple affinity states $(2,10,15,20)$, and by comparison of dose-response relationships for binding and resultant physiological events, the occupancy of specific affinity states of the receptor has been related to the observed biological responses. CCK-stimulated secretion of digestive enzymes and protein synthesis are attributed to binding to a highaffinity state of the receptor, whereas inhibition of secretion and protein synthesis, together with the stimulation of glucose transport, by supramaximal concentrations are thought to be mediated by binding to a low-affinity state $(13,15,20,29,30)$. Much of the evidence for this concept has been obtained using the partial analogue of CCK-8, JMV-180 $(6,7,15,16,23)$ (Table 1), which has been reported to act as an agonist at the high-affinity state of the $\mathrm{CCK}_{\mathrm{A}}$ receptor. Paradoxically, although stimulation with JMV-180 results in full secretion, it does not appear to activate an identical sequence of transduction events compared to $\mathrm{CCK}$. For example, the binding of CCK-8 to the $\mathrm{CCK}_{\mathrm{A}}$ re- ceptor has been reported to be guanine nucleotide sensitive, whereas the binding of CCK-OPE, a similar analogue to JMV180 , is not (6). Moreover, JMV-180, in contrast to CCK, appears to increase intracellular $\mathrm{Ca}^{2+}$ by an $1,4,5-\mathrm{IP}_{3}$ independent route, because $\mathrm{Ca}^{2+}$ signaling stimulated by this molecule is insensitive to inhibitors of phospholipase C-coupled events or to inhibitors of the $I_{3}$ receptor $(19,26,31)$. These studies suggest that JMV180 and $\mathrm{CCK}$, although binding to the same receptor, may activate distinct transduction mechanisms. Although only a little is known about binding domains of peptide receptors, evidence from study of the $\mathrm{CCK}_{\mathrm{B}}$ receptor has indicated that different sites may be responsible for conferring either agonist or antagonist binding properties (1). In this study, we have investigated the possibility that JMV-180 and CCK-8 bind to different sites on the $\mathrm{CCK}_{\mathrm{A}}$ receptor by investigating the interaction of antagonists and agonists of the $\mathrm{CCK}_{\mathrm{A}}$ receptor.

\section{METHOD}

\section{Chemicals}

Fura-2/AM and fura-2 free acid was purchased from Molecular Probes (Eugene, OR); lorglumide (also known as CR 1409)

\footnotetext{
${ }^{1}$ Requests for reprints should be addressed to David I. Yule, Department of Physiology, University of Michigan, 7737 Med Sci II, Ann Arbor, MI 48109-0622.
} 
TABLE 1

AMINO ACID SEQUENCES OF CCK ANALOGUES

CCK-8 Asp-Tyr( $\left.\mathrm{SO}_{3} \mathrm{H}\right)$-Met-Gly-Trp-Met-Asp-Phe- $\mathrm{NH}_{2}$

Trp-Met-Asp-Phe-NH

JMV-180 Boc-Tyr( $\left.\mathrm{SO}_{3} \mathrm{H}\right)$-Ahx-Gly-Trp-Ahx-Asp-phenylethylester

JMV-179 Boc-Tyr( $\left.\mathrm{SO}_{3} \mathrm{H}\right)$-Ahx-Gly-DTrp-Ahx-Asp-phenylethylester

Primary amino acid sequence of CCK and the analogues utilized during this study. The primary functional modification in JMV-180 is at the carboxy-terminus. In JMV-179 a D-Trp for L-Trp substitution has been made. Boc $=t$-butyloxycarbonyl; Ahx $=6$ aminohexanoic acid (norleucine).

was from RBI (Natick, MA); JMV-180 and JMV-179 were from Research Plus (Bayonne, NJ); collagenase was from Worthington Biochemicals (Freehold, NJ); bovine serum albumin (fraction V) was from ICN Imunobiologicals (Lisle, IL); minimal essential amino acids were from GIBCO (Grand Island, NY); L-364,718 (also known as MK-329 or devazepide) was a gift from Merck Sharp and Dohme (West Point, PA). CCK-8 was a gift from Squibb Research Institute (Princeton, NJ). All other chemicals were obtained from Sigma Chemical (St. Louis, MO).

\section{Preparation of Pancreatic Acini}

Acini were prepared by methods as previously described $(16,28,31)$. In brief, pancreata were excised from fed adult male Sprague-Dawley rats (200-250 g) and acini were prepared by enzymatic digestion with purified collagenase. Acini were then suspended in a physiological salt solution (PSS) containing an essential amino acid mixture, $10 \mathrm{mg} / \mathrm{ml} \mathrm{BSA}, 0.1 \mathrm{mg} / \mathrm{ml}$ soybean trypsin inhibitor (SBTI), and (in $\mathrm{mM}$ ): $137 \mathrm{NaCl}, 4.7 \mathrm{KCl}, 0.56$ $\mathrm{MgCl}_{2}, 1.28 \mathrm{CaCl}_{2}, 1.0 \mathrm{Na}_{2} \mathrm{HPO}_{4}, 10$ HEPES, 2 L-glutamine, 5.5 D-glucose. The $\mathrm{pH}$ was adjusted to 7.4 and equilibrated with $100 \% \mathrm{O}_{2}$.

\section{Measurement of Intracellular $\left[\mathrm{Ca}^{2+}\right]_{i}$}

Isolated acini were incubated with $1 \mu M$ fura-2/AM at ambient temperature for $30 \mathrm{~min}$ and then washed and resuspended in fresh PSS. For measurement of intracellular $\left[\mathrm{Ca}^{2+}\right]$, fura-2loaded acini were transferred to a closed $100-\mu 1$ chamber, mounted on the stage of a Zeiss Axiovert inverted microscope, and continuously superfused at $1 \mathrm{ml} / \mathrm{min}$ with PSS at $37^{\circ} \mathrm{C}$. Solution changes were rapidly accomplished by means of a valve attached to an eight-chambered superfusion reservoir. Measurement of intracellular $\left[\mathrm{Ca}^{2+}\right]$ was performed using an Attofluor digital imaging system (Rockville, MD). In brief, excitation of cells at 334 and 380 (10 $\mathrm{nm}$ bandpass) was accomplished by a computer-selectable filter and shutter system. Resultant emission at $510 \mathrm{~nm}$ was monitored by an intensified CCD camera and subsequently digitized. Calibration of $\left[\mathrm{Ca}^{2+}\right]_{i}$ signals was determined by applying the equation of Grynkiewicz (9). The fluorescent emission of external $\mathrm{Ca}^{2+}$ standards containing 1 $\mu M$ fura-2 either in the absence (1 $\mathrm{m} M$ EGTA) or presence of $\mathrm{Ca}^{2+}(1 \mathrm{~m} M)$ was monitored allowing the determination of $\boldsymbol{R}_{\max }$, $R_{\min }$ and $\beta$. The calibration was then applied to user-defined areas of interest, where mean gray level values were computed to give a measurement of $\left[\mathrm{Ca}^{2+}\right]_{\mathrm{i}}$ as described previously $(3,32,33)$.

\section{Measurement of Amylase Release}

Acini were incubated for $30 \mathrm{~min}$ in the presence of the indicated agents. In samples incubated with both antagonists and agonists, the antagonists were added $30 \mathrm{~s}$ prior to addition of agonists. After stimulation of acini, samples were centrifuged for $10 \mathrm{~s}$ in an Eppendorf microcentrifuge. Amylase was determined in the supernatant using procion yellow starch as substrate (12). At the beginning of the incubation period, a $1-\mathrm{ml}$ aliquot of acinar suspension was centrifuged and amylase determined in the supernatant. This zero time value was subtracted from the values obtained after incubation. The pellets were resuspended in water and sonicated to determine total acinar amylase content. Amylase release during incubation was expressed as percentage of the total amylase content at the beginning of the incubation.

RESULTS

L-364,718 Inhibits $\mathrm{Ca}^{2+}$ Oscillations Induced by CCK But Not JMV -180

On stimulation with low concentrations of CCK-8 or JMV. 180 the intracellular $\left[\mathrm{Ca}^{2+}\right]_{i}$ signal showed a characteristic oscillatory increase. The $\left[\mathrm{Ca}^{2+}\right]$ signal rose from basal values of $96 \pm 3 \mathrm{n} M(28 \mathrm{expt}, 325$ cells $)$ and peaked at $313 \pm 27 \mathrm{n} M$ for $20 \mathrm{p} M$ CCK-8 (10 expt, 107 cells) or $277 \pm 19 \mathrm{n} M$ for $1 \mu M$ JMV-180 (12 expt, 142 cells). The periodicity of $\mathrm{Ca}^{2+}$ oscillations stimulated by CCK and JMV-180 was similar to that previously reported; oscillations stimulated by JMV-180 were somewhat more rapid than those evoked by low concentrations of CCK-8 (16). The pattern of $\mathrm{Ca}^{2+}$ signal evoked by CCK-8 has been shown to be influenced by the concentration of agonist applied; at higher concentrations of CCK-8 an oscillating $\mathrm{Ca}^{2+}$ signal is superseded by a rapid peak followed by a plateau that is maintained throughout the period of agonist exposure [Fig. 1(A-C)]. In contrast, JMV-180 has been shown to exclusively initiate an oscillatory $\mathrm{Ca}^{2+}$ signal [Fig. 1(D-F)]. After initiation of a $\mathrm{Ca}^{2+}$ signal with CCK-8 (10 pM-1 $\mathrm{n} M)$, concurrent superfusion of $0.1 \mu M \mathrm{~L}-364,718$, a benzodiazapine derivative, which is a specific antagonist of the $\mathrm{CCK}_{\mathrm{A}}$ receptor (5), resulted in a rapid, marked attenuation of the $\mathrm{Ca}^{2+}$ signal [Fig. 1(A-C)] (10 pM: 3 expt, 56 cells: $100 \mathrm{pM}: 3$ expt, 23 cells; $1 \mathrm{n} M: 2$ expt, 12 cells). Cells stimulated with $1 \mu M$ CCK-4 also increased $\left[\mathrm{Ca}^{2+}\right]_{i}$ in an oscillatory manner to a peak of $248 \pm 30 \mathrm{nM}$ (6 expt, 76 cells). Oscillations stimulated by CCK-4 were also inhibited by $0.1 \mu M$ L-364,718 (Fig. 2) (3 expt, 26 cells), indicating that the terminal four amino acid fragment of CCK-8 induces similar $\mathrm{Ca}^{2+}$ signaling to CCK-8, although with decreased affinity. In contrast, oscillations induced by JMV-180 over the concentration range of $25 \mathrm{n} M-1 \mu M$ were essentially unaffected by concurrent superfusion of L-364,718 at similar concentrations [Fig. 1(D-F)] (25 $\mathrm{n} M: 3$ expt, 15 cells; $100 \mathrm{n} M: 3$ expt, 13 cells; $1 \mu M: 3$ expt, 34 cells). The effect of $\mathrm{L}-364,718$ was not assessed below $25 \mathrm{nM}$ JMV-1 80 because these concentrations rarely induced prolonged, regular $\mathrm{Ca}^{2+}$ oscillations.

\section{Lorglumide Inhibits $\mathrm{Ca}^{2+}$ Oscillations Induced by CCK But Not JMV-180}

To determine that the differential effect of $L-364,718$ to inhibit CCK-8- but not JMV-180-induced oscillations was not unique to one chemical class of antagonist, the effects of lorglumide $(5,14,17)$, a potent glutaramic acid derivative antagonist, were studied. In cells stimulated with low concentrations of CCK- 

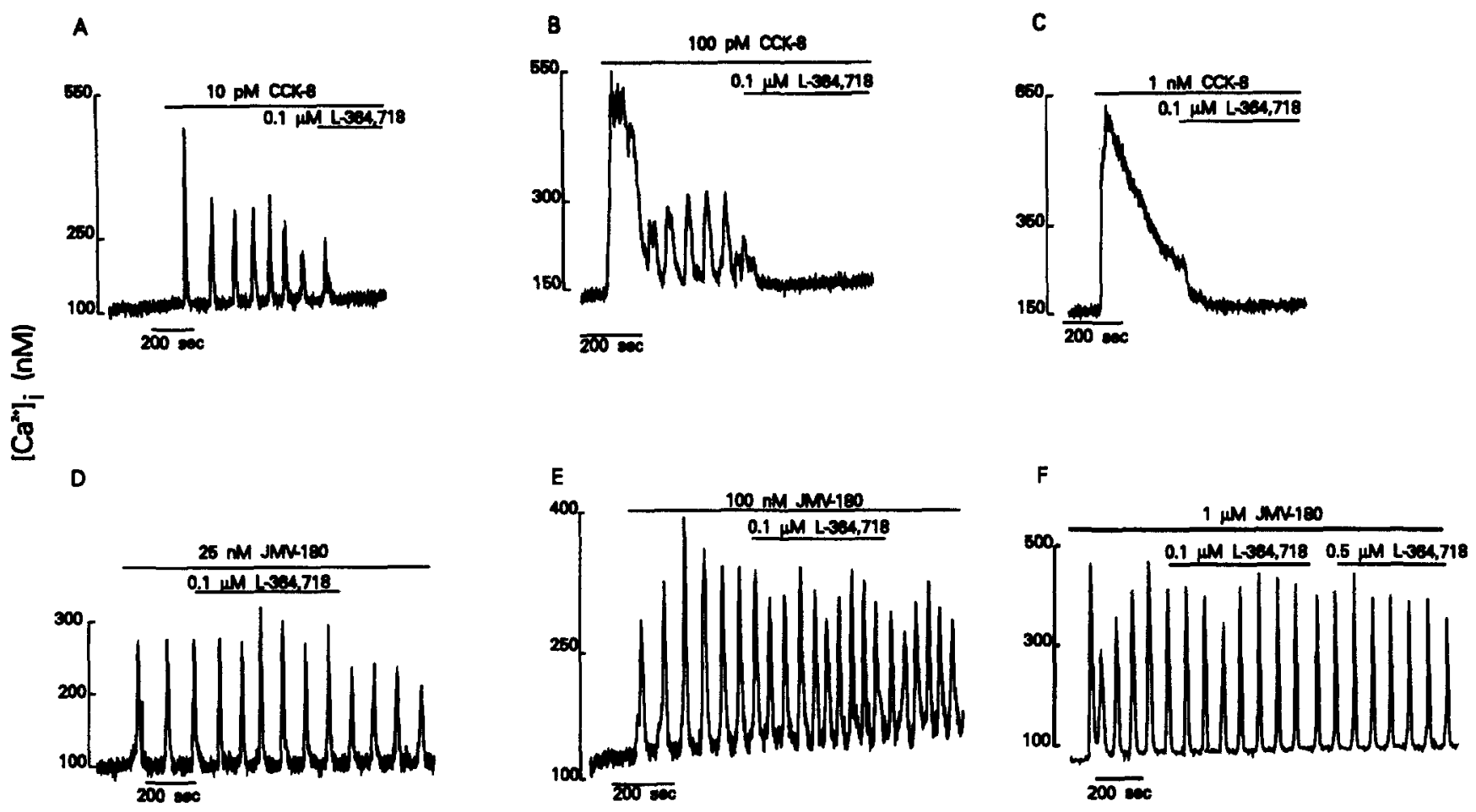

FIG. 1. L-364,718 inhibits CCK- but not JMV-180-induced $\mathrm{Ca}^{2+}$ signaling. (A-C) Superfusion of CCK-8 induces an increase in [Ca $\left.{ }^{2+}\right]_{\mathrm{i}}$. Concurrent superfusion of $\mathrm{L}-364,718$ rapidly attenuates the rise in $\left[\mathrm{Ca}^{2+}\right]_{i}$. (D-F) In contrast, oscillations stimulated by JMV-180 are unaffected by $\mathrm{L}-364,718$, even at greater concentrations.

$8, \mathrm{Ca}^{2+}$ oscillations were rapidly inhibited by concurrent superfusion with $10 \mu M$ lorglumide [Fig. 3(A)] (4 expt, 32 cells). Oscillations stimulated by superfusion of $\mathrm{CCK}-4$ were also inhibited by lorglumide ( 2 expt, 40 cells). In contrast, oscillations initiated by superfusion of JMV-180 (100 $\mathrm{nM}$ or $1 \mu M)$ were largely unaffected by administration of $10 \mu M$ lorglumide [Fig. 3(B)] ( 100 $\mathrm{n} M$ : 3 expt, 34 cells; $1 \mu M: 4$ expt, 33 cells). Furthermore, this differential antagonism could be seen in individual cells stimulated with both agonists. In cells first stimulated with $20 \mathrm{pM}$ CCK-8, $\left[\mathrm{Ca}^{2+}\right]_{\text {; }}$ oscillations could be inhibited by lorglumide; however, in the continued presence of the antagonist, $\left[\mathrm{Ca}^{2+}\right]_{i}$ oscillations could still be initiated by JMV-180 (1 $\mu M)$ [Fig. $3(\mathrm{C})]$.

\section{JMV-179 Inhibits $\mathrm{Ca}^{2+}$ Oscillations Induced by Both CCK and $J M V-180$}

A third recently described $\mathrm{CCK}_{\mathrm{A}}$ antagonist is a D-Trp-substituted analogue of JMV-180, termed JMV-179, which has been shown to exhibit characteristics of a pure antagonist (22). Because this molecule has close structural similarities to both CCK and JMV-180, its ability to inhibit $\mathrm{Ca}^{2+}$ signaling by these molecules was tested. In cells stimulated by CCK, in which oscillations had been initiated, concurrent superfusion of $1 \mu M \mathrm{JMV}-179$ resulted in the complete inhibition of the signal [Fig. 4(A)] (3 expt, 19 cells). In a similar manner, JMV-179 at concentrations in 10-fold excess markedly attenuated the oscillating $\mathrm{Ca}^{2+}$ signal stimulated by $100 \mathrm{n} M$ or $1 \mu M \mathrm{JMV}-180$ [Fig. $4(\mathrm{~B}, \mathrm{C})](100 \mathrm{n} M$ : 5 expt, 84 cells; $1 \mu M: 5$ expt, 75 cells). The attenuation of the signal was somewhat more rapid with lower concentrations of JMV-180 [compare Fig. 4(B) and 4(C)] and when the JMV-179 was added in 100-fold excess (data not shown). This inhibition of JMV-180-induced $\mathrm{Ca}^{2+}$ signaling by JMV-179 was also evident in cells preexposed to L-364,718 (3 expt, 12 cells) [Fig. $4(C)$, possibly indicating that inhibition of $\mathrm{Ca}^{2+}$ signaling by JMV-179 and L-364,718 is not mediated by binding to an identical site on the receptor.

\section{Effects of $C C K_{A}$ Antagonists on CCK- and JMV-180-Induced Amylase Secretion}

The primary physiological consequence of $\left[\mathrm{Ca}^{2+}\right]_{i}$ oscillations induced by CCK- 8 and $\mathrm{JMV}-180$ is the secretion of digestive enzymes from the pancreatic acinar cell. The above data would predict that enzyme secretion in response to CCK-8 would be

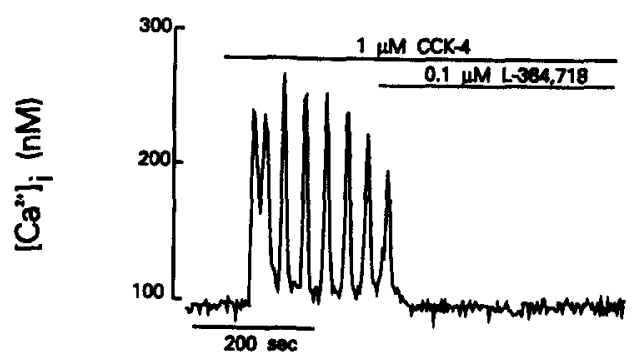

FIG. 2. L-364,718 inhibts CCK-4-induced $\mathrm{Ca}^{2+}$ signaling. Superfusion of CCK-4 induces an oscillatory increase in $\left[\mathrm{Ca}^{2+}\right]_{i}$, which is rapidly attenuated by concurrent superfusion with $L, 364,718$. 
A
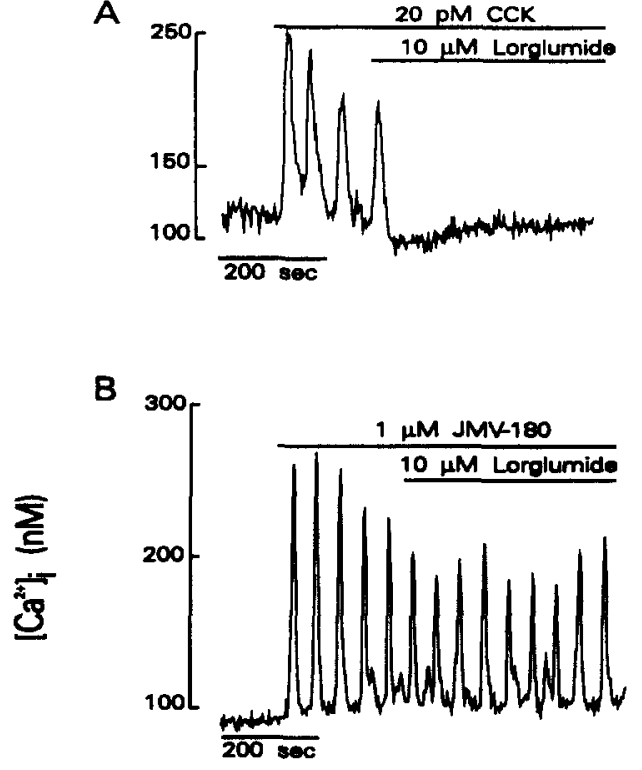

C

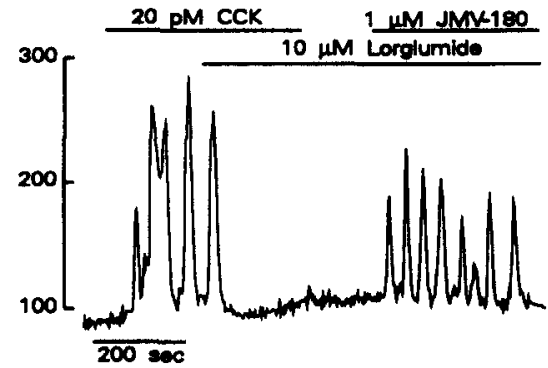

FIG. 3. Lorglumide inhibits CCK- but not JMV-180-induced $\mathrm{Ca}^{2+}$ signaling. (A) $\mathrm{Ca}^{2+}$ oscillations induced by CCK are rapidly inhibited by lorglumide back to basal values. (B) In contrast, $\mathrm{Ca}^{2+}$ oscillations stimulated by JMV-180 are largely unaffected. (C) In a similar manner to (A), $\mathrm{Ca}^{2+}$ oscillations stimulated by $\mathrm{CCK}$ are inhibited by lorglumide. After CCK is removed in the continued presence of lorglumide, $\mathrm{Ca}^{2+}$ oscillations can still be initiated by JMV-180.

inhibited by all receptor antagonists. In contrast, secretion induced by JMV-180 should only be affected by JMV-179, but not by $L, 364,718$ and lorglumide. That this is indeed the case, as shown in Table 2. Amylase secretion in response to an optimum concentration of CCK-8 $(100 \mathrm{p} M)$ increased from basal values of $4.2 \pm 0.8 \%$ of total to $22.2 \pm 1.9 \%(n=4)$. The increase above basal was markedly inhibited by L-364,718 (91\% reduction), lorglumide ( $74 \%$ reduction), and JMV-179 (>99\% reduction). In contrast, secretion induced by $1 \mu M \mathrm{JMV}-180$ was not significantly attenuated by L-364,718 (14\% reduction) or lorglumide (no inhibition). However, treatment with $10 \mu M \mathrm{JMV}$ 179 reduced the responses induced by JMV- 180 by $96 \%$.

\section{DISCUSSION}

Studies of structure-activity relationships for CCK and its analogues have defined regions of the peptide that are essential for binding and the consequent stimulation of intracellular signaling and biological responses. CCK-8, containing an unsulphated tyrosine, initiates the full spectrum of biological events, although it is some 1000 times less potent when compared to
CCK-8 containing $\operatorname{Tyr}\left(\mathrm{SO}_{3} \mathrm{H}\right)$, and thus a sulphated Tyr is required for full potency of the peptide $(11,18)$. Carboxy-terminus fragments of CCK-8 as short as CCK-4 (see Table 1) will stimulate a full range of physiological events in rat and mouse acini, including binding to at least two affinity states of the receptor and the stimulation of biphasic amylase secretion (21). These data suggest that the four terminal amino acids confer important information for the correct interaction of the CCK to its receptor even though the potency of CCK-4 is 30,000-100,000-fold weaker compared to sulphated CCK-8 (21). The above studies indicate that interaction of the CCK peptide with multiple residues on the $\mathrm{CCK}_{\mathrm{A}}$ receptor may be important for fully potent and efficacious transduction of the signal. At a minimum, a residue in the receptor appears to interact with the sulphated Tyr moiety in the amino-terminal of the peptide to confer potency, whereas the carboxy-terminal four amino acids convey information regarding the range of biological responses stimu-

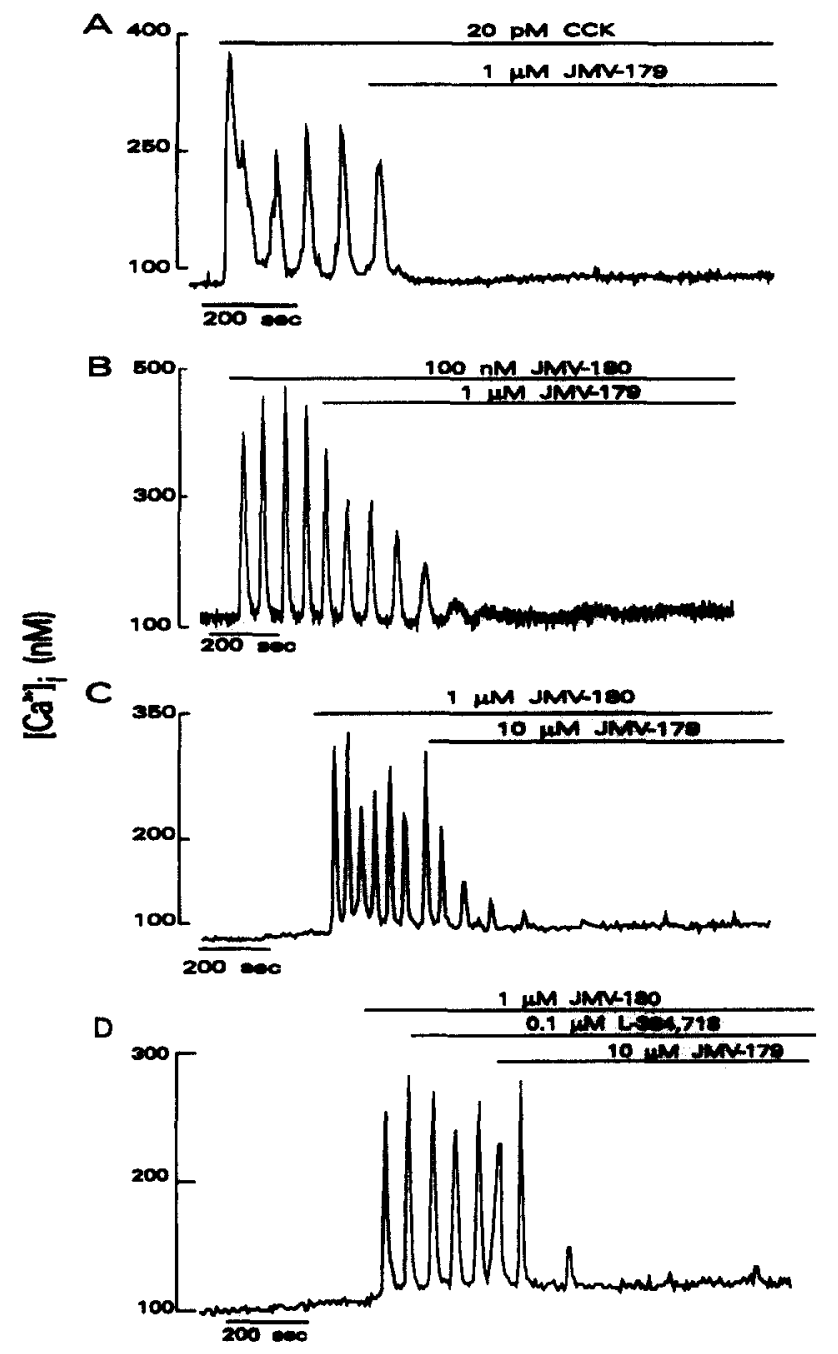

FIG. 4. JMV-179 inhibits oscillations stimulated by both CCK-8 and JMV-180. (A) $\mathrm{Ca}^{2+}$ oscillations stimulated by CCK are inhibited by concurrent incubation with $\mathrm{JMV}-179$. (B,C) $\mathrm{Ca}^{2+}$ oscillations stimulated by JMV-180 are also markedly attenuated by concurrent superfusion with JMV-179 at concentrations in tenfold excess. (D) Oscillations stimulated by JMV-180 are also inhibited by JMV-179 in the continued presence of $\mathrm{L}-364,718$. 
TABLE 2

AMYLASE SECRETION STIMULATED BY CCK AND JMV-180 IS DIFFERENTIALLY INHIBITED BY ANTAGONISTS OF CCK $_{\wedge}$ RECEPTORS

\begin{tabular}{lrrrr}
\hline & No Addition & \multicolumn{1}{c}{$\begin{array}{c}\text { L-364,718 } \\
(0.1 \mu M)\end{array}$} & $\begin{array}{c}\text { Lorglumide } \\
(10 \mu M)\end{array}$ & \multicolumn{1}{c}{$\begin{array}{c}\text { JMV-179 } \\
(10 \mu M)\end{array}$} \\
\hline Basal & $4.2 \pm 0.8$ & $4.2 \pm 0.3$ & $5.1 \pm 0.6$ & $5.5 \pm 0.5$ \\
CCK-8 $(100 \mathrm{p} M)$ & $22.2 \pm 1.9$ & $5.7 \pm 0.3$ & $9.5 \pm 0.6$ & $5.6 \pm 1.9$ \\
JMV-180 $(1 \mu M)$ & $22.5 \pm 2.5$ & $20.1 \pm 0.6$ & $22.4 \pm 1.5$ & $6.1 \pm 1.4$ \\
\hline
\end{tabular}

Amylase secretion stimulated by optimum concentrations of CCK-8 and JMV-180 over $30 \mathrm{~min}$ was compared in the presence and absence of the indicated antagonists: L-364,718, lorglumide, and JMV-179. Data are the mean \pm SEM of three to four experiments and represent the percent of total amylase released compared with the total measured in the pellets. In individual experiments amylase release for each condition was determined in triplicate.

lated. This later receptor site is sensitive to the amidated carboxylterminal of the peptide, as CCK derivatives with a free carboxyl group are biologically inactive (18).

Modification of CCK-8 to form JMV-180 (Table 1) has also yielded important information because this molecule only interacts with one affinity state of the receptor and stimulates a subset of CCK-8's action $(6,7,15,16,19,23,26,31)$. The important modification to the JMV-180 molecule appears to be to the carboxy-terminus of the molecule where aspartate is linked by an ester bond to phenylamine instead of the peptide bond linkage to the terminal-amidated phenyalanine in CCK-8. Other modifications to the JMV-180 molecule, including substitution of norleucine for methionine residues and the presence of an aminoterminal $t$-butyloxycarbonyl group, only confer increased stability to the molecule because these substitutions in CCK-7 or CCK-9 do not affect biological activity (7).

We have shown that $\mathrm{Ca}^{2+}$ signaling and amylase secretion stimulated by CCK and JMV-180 are differentially inhibited by antagonists of the $\mathrm{CCK}_{\mathrm{A}}$ receptor; that is, antagonists from distinct chemical classes inhibit responses stimulated by $\mathrm{CCK}$ but are largely ineffective at attenuating responses initiated by JMV180 over a large concentration range. That this affect appears to be an integral property of the receptor and not a function of JMV-180 binding irreversibly to the receptor is indicated by the inability of nonpeptide antagonist to inhibit JMV-180-stimulated $\mathrm{Ca}^{2+}$ signaling when the antagonist has been incubated prior to superfusion of JMV-180 [Fig. 3(C)].

One manner in which this paradoxical data can be reconciled is by the model shown in Fig. 5, representing the high-affinity state of the $\mathrm{CCK}_{\mathrm{A}}$ receptor, in which CCK-8/CCK-4 and JMV180 bind to discrete residues on the $\mathrm{CCK}_{\mathrm{A}}$ receptor. Both $\mathrm{CCK}$ 8 and CCK-4 are envisioned to interact with multiple sites, whereas JMV-180, because of modifications to the $C$-terminus, is only capable of binding to a subset of the sites needed for full biological activity [Fig. 5(A-C)]. Thus, the binding of JMV-180 could result in a unique conformational change leading to the observed distinct biological events, such as guanine nucleotideinsensitive binding and the apparent stimulation of $1,4,5-\mathrm{IP}_{3}$ independent $\mathrm{Ca}^{2+}$ signaling $(6,19,26,31)$. Little information is available regarding specific amino acid residues or domains of the $\mathrm{CCK}_{\mathrm{A}}$ receptor that are important for interaction with the peptide. However, evidence from the study of bacteriorhodopsin, together with the cholinergic and adrenergic receptor, suggests that multiple regions of the receptor may be important for correct interaction (27). Specifically, site-directed mutagenesis of cate- cholamine receptors has indicated that ligand binding is determined by interaction with at least three residues within the binding pocket formed between transmembrane domains; serine residues in the fifth transmembrane domain interact with hydroxyl moieties, whereas a phenylalanine residue in the sixth transmembrane domain is important for interaction with the aromatic ring structure of catecholamines (25). An aspartate residue in the third transmembrane domain is the third requirement essential for fully efficacious binding of biogenic amines to their receptors. The aspartate residue appears important in recognition of the amine portion of the molecule because this residue is highly conserved in other receptors that bind amines, such as the muscarinic acetylcholine receptor $(4,24)$.

This model (Fig. 5) predicts that classical antagonists of the $\mathrm{CCK}_{\mathrm{A}}$ receptor are not effective in inhibiting the responses stimulated by JMV- 180 because interaction of antagonist with receptor does not interfere with binding to the discrete sites needed for JMV-180 activity. Although not necessary for the model, in

A.

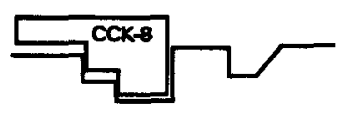

B.

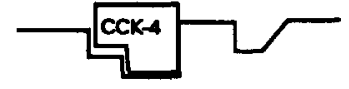

C.

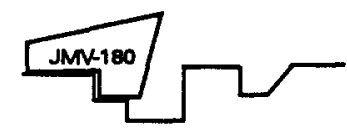

D.

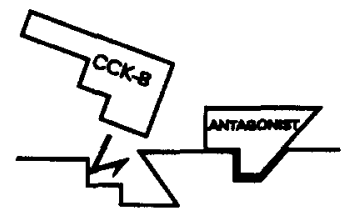

E.

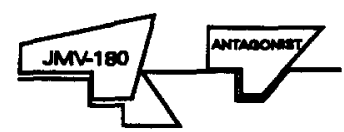

$$
\text { F. }
$$

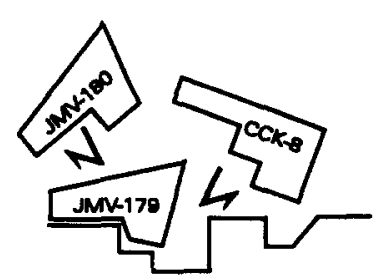

FIG. 5. Model of CCK and JMV-180 binding to the $\mathrm{CCK}_{\mathrm{A}}$ receptor. Cartoon represents a model in which CCK and JMV-180 bind to different sites on the $\mathrm{CCK}_{\mathrm{A}}$ receptor. (A) CCK-8 binding to the receptor. (B) CCK-4 binding to the receptor. (C) JMV-180 binding to the receptor. (D) Nonpeptide antagonist binding (L-364,718, lorglumide) inhibits the binding of CCK by altering the conformation of the receptor. (E) Altered conformation of the receptor is not sufficient to inhibit JMV-180 binding. (F) JMV-179 binding, by occupying the sites required for JMV-180 action, inhibits both JMV-180 and CCK 
the cartoon shown in Fig. 5 the binding of antagonist is depicted as occurring at a distinct site somewhat distant to the agonist binding pocket. Evidence for this is not available relating to the $\mathrm{CCK}_{\mathrm{A}}$ receptor, but a recent study has indicated that a region important for nonpeptide antagonist binding is located in the sixth transmembrane loop of the $\mathrm{CCK}_{\mathrm{B}}$ receptor, because substitution of a single amino acid in position 319 dramatically alters nonpeptide antagonist binding properties, without affecting the binding of agonists. A similar situation has been reported for the tachykinin receptor; chimeric substitution of a 17 amino acid region between $\mathrm{NK}_{1}$ and $\mathrm{NK}_{2}$ receptors reverses antagonist specificity without altering agonist binding. The authors of these studies therefore concluded that agonist and antagonist determinant residues reside in differing regions of the receptor $(1,8)$.

Data in Fig. 4 show that JMV-179 will antagonize $\mathrm{Ca}^{2+}$ signaling and amylase secretion not only elicited by CCK-8, but also by JMV-180 [Fig. 4(A-C)]. Although the mechanism for JMV-179-mediated inhibition is unknown at this time, it seems likely that because this molecule is very similar in structure to JMV-180 (Table 1), having only one substitution (D-Trp for LTrp), that it interacts with the same site(s) in the receptor as JMV-180. Thus, inhibition of JMV-180 binding could occur as a function of competition for this site. That the sites sufficient for JMV-179-mediated inhibition may differ from those normally occupied by nonpeptide antagonists such as L-364,718 is indicated by the ability of JMV-179 to inhibit responses to JMV180 in the presence of the nonpeptide antagonist. Inhibition of CCK-8 responses would then occur as occupation of the site normally occupied by JMV-180 would interfere with binding of CCK-8 [Fig. 5(F)]

In the present study, we reported differences in the ability of antagonists of the $\mathrm{CCK}_{\mathrm{A}}$ receptor to inhibit responses elicited by CCK and its partial agonist JMV-180. We proposed a model based on the binding of JMV-180 and CCK to differing yet overlapping sites or residues in the $\mathrm{CCK}_{\mathrm{A}}$ receptor to explain not only the differing susceptibility to antagonists but maybe to explain how two agonists binding to one receptor can elicit differing physiological responses.

\section{ACKNOWLEDGEMENTS}

This work was supported by NIH Grant DK41225, the Michigan Gastrointestinal Peptide Center (DK34933), and by the Michigan Diabetes Research and Training Center (DK20572). The authors wish to thank E. Steunkel and C. Logsdon for helpful discussion during the period of this study.

\section{REFERENCES}

1. Beinborn, M.; Lee, Y-M.; McBride, E. W.; Quinn, S. M.; Kopin, A. S. A single amino acid of the cholecystokinin-B/gastrin receptor determines specificity for non-peptide antagonists. Nature 362:348$350 ; 1993$.

2. Blevins, G. T.; Williams, J. A. ATP induces two cholecystokinin binding affinity states in permeabilized rat pancreatic acini. Am. J Physiol. 263:G44-G51; 1992.

3. Brooker, G.; Seki, T.; Croll, D.; Wahlestedt. C. Calcium wave evoked by activation of endogenous or exogenously expressed receptors in Xenopus oocytes. Proc. Natl. Acad. Sci. USA 87:2813-2817; 1990.

4. Fraser, C. M.; Wang, C-D.; Robinson, D. A.; Gocayne, J. D.; Venter, J. C. Site directed mutagenesis of $\mathrm{m} 1$ muscarinic acetylcholine receptors: Conserved aspartic acids play important roles in receptor function. Mol. Pharmacol. 36:840-847; 1989.

5. Freidinger, R. M. Cholecystokinin and gastrin antagonists. Med. Res. Rev. 9:271-290; 1989.

6. Gaisano, H. Y.; Klueppelberg, U. G.; Pinon, D. I.; Pfenning, M. A.; Powers, S. P.; Miller, L. J. Novel tool for the study of cholecystokininstimulated enzyme secretion. J. Clin. Invest. 83:321-325; 1989.

7. Galas, M. C.; Lignon, M. F.; Rodriguez, M.; et al. Structure activity relationships studies on cholecystokinin: Analogues with partial agonist activity. Am. J. Physiol. 254:G176-G182; 1988.

8. Gether, U.; Yokato, Y.; Emonds-Alt, X.; et al. Two nonpeptide tachykinin antagonists act through epitopes on corresponding segments of the $\mathrm{NK}_{1}$ and $\mathrm{NK}_{2}$ receptor. Proc. Nat. Acad. Sci. USA 90: 6194-6198; 1993.

9. Grynkiewicz, G.; Poenie, M.; Tsien, R. Y. A new generation of $\mathrm{Ca}^{2+}$ indicators with greatly improved fluorescent properties. J. Biol. Chem. 260:3440-3450; 1985 .

10. Jensen, R. T.; Lemp, G. F.; Gardner, J. D. Interaction of cholecystokinin with specific membrane receptors on pancreatic acinar cells. Proc. Natl. Acad. Sci. USA 77:2079-2083; 1980.

11. Johnson, L. R.; Stening, G. F.; Grossman, M. I. Effects of sulphation on the gastrointestinal actions of caerulein. Gastroenterology 58: 208-216; 1970.

12. Jung, D. H. Preparation and application of procion yellow starch for amylase assay. Clin. Chem. Acta 100:7-11; 1980.

13. Korc, M.; Williams, J. A.; Goldfine, I. D. Stimulation of the glucose transport system in isolated mouse pancreatic acini by cholecystokinin and analogues. J. Biol. Chem. 252:7624-7629; 1979.

14. Makovec, F.; Bani, M.; Chiste, L. R.; Revel, L.; Rovati, L. C.; Rovati, L. A. Differentiation of central and peripheral cholecystokinin re- ceptors by new glutaramic acid derivatives with cholecystokininantagonist activity. Arzneimittelforschung 36(1):98-102; 1986.

15. Matozaki, T.; Martinez, J.; Williams, J. A. A new CCK analogue differentiates two functionally distinct CCK receptors in rat and mouse acini. Am. J. Physiol. 257:G594-G600; 1989.

16. Matozaki, T.; Goke, B.; Tsunoda, Y.; Rodriguez, M.; Martinez, J.; Williams. J. A. Two functionally distinct cholecystokinin receptors show different modes of actions on $\mathrm{Ca}^{2+}$ mobilization and phospholipid hydrolysis in isolated rat pancreatic acini. J. Biol. Chem. 265:6247-6254; 1990.

17. Niederau, C.; Niederau, M.; Williams, J. A.; Grendell, J. H. New proglumide-analogue $C \mathrm{CK}$ receptor antagonists: Very potent and selective for peripheral tissues. Am. J. Physiol. 251:G856-G860; 1986.

18. Rehfield. J. F. Four basic characteristics of the gastrin-cholecystokinin system. Am. J. Physiol. 240:G255-G266; 1981.

19. Saluja, A. K.; Dawra, R.; Lerch, M.; Steer, M. L. CCK-JMV-180, an analogue of cholecystokinin, releases calcium from an inositol trisphosphate independent pool in rat pancreatic acini. J. Biol. Chem. 267:11202-11208; 1992.

20. Sankaran, H.; Goldfine, I. D.; Deveney, C. W.; Wong, E. Y.; Williams, J. A. Binding of cholecystokinin to high affinity receptors on isolated rat pancreatic acini. J. Biol. Chem. 255:1849$1853 ; 1980$.

21. Sankaran, H.; Bailey, A. C.; Williams, J. A. CCK-4 contains full hormonal information of cholecystokinin in isolated pancreatic acini. Biochem. Biophys. Res. Commun. 103(4):1356-1362; 1981.

22. Silvente-Poirot, S.; Hadjivanova, C.; Escrieut, C.; et al. Study of the states and populations of the rat pancreatic cholecystokinin receptor using the full peptide antagonist JMV-179. Eur. J. Biochem. 212: 529-538; 1993.

23. Stark, H. A.; Sharp, C. M.; Sutliff, V. E.; Martinez, J.; Jensen, R. T.; Gardner, J. D. CCK-JMV-180: A peptide that distinguishes high-affinity from low-affinity cholecystokinin receptors. Biochem. Biophys. Acta 1010:145-150; 1989.

24. Strader, C. D.; Sigal, I. S.; Register, R. B.; Candelore, M. R.; Rands, E.; Dixon, R. A. Identification of residues required for ligand binding to the beta-adrenergic receptor. Proc. Natl. Acad. Sci. USA 84:4384 4388; 1987

25. Strader, C. D.; Sigal, I. S.; Dixon, R. A. Structural basis of beta adrenergic receptor function. FASEB J. 3:1825-1832; 1989. 
26. Tsunoda, Y.; Owang, C. Differential involvement of phospholipase A2/phosphoinositol pathways during cholecystokinin receptor activated Ca ${ }^{2+}$ oscillations in pancreatic acini. Biochem. Biophys. Res. Commun. 194:1194-1202; 1993.

27. Weiss, J. Mutational analysis of muscarinic acetylcholine receptors: Structural basis of ligand/receptor/gprotein interactions. Life Sci. 53:1447-1463; 1993.

28. Williams, J. A.; Korc, M.; Dormer, R. L. Action of secretagogues on a new preparation of functionally intact, isolated pancreatic acini. Am. J. Physiol. 235:E517-E524; 1978.

29. Williams, J. A.; Blevins, G. T., Jr. Cholecystokinin and regulation of pancreatic acinar cell function. Physiol. Rev. 73(4):701-723; 1993.
30. Williams, J. A.; Yule, D. I. Stimulus-secretion coupling in pancreatic acinar cells. In: Go, V. W., ed. The pancreas, biology pathobiology and disease. New York: Raven Press; 1993:167-189.

31. Yule, D. I.; Williams, J. A. U73122 inhibits $\mathrm{Ca}^{2+}$ oscillations in response to cholecystokinin and carbachol but not JMV-180 in rat pancreatic acini. J. Biol. Chem. 267:13830-13835; 1992.

32. Yule, D. I.; Tseng, M-J.; Williams, J. A.; Logsdon, C. D. A cloned CCK-A receptor transduces multiple signals in response to full and partial agonists. Am. J. Physiol. 265:G999-G1004; 1993.

33. Yule, D. I.; Wu, D.; Essington, T. E.; Shayman, J. A.; Williams, J. A. Sphingosine metabolism induces $\mathrm{Ca}^{2+}$ oscillations in rat pancreatic acinar cells. J. Biol. Chem. 268:12353-12358; 1993. 